\title{
COMMENTS
}

\section{Constitutional Limitations on State Long Arm Jurisdiction}

\section{In International Shoe Co. v. Washington, ${ }^{1}$ the Supreme Court}

defined due process himitations on state jurisdiction over nonresidents in terms of the "fair" result on the merits of each case, ${ }^{2}$ rejecting the application of fixed rules. ${ }^{3}$ This emphasis has led the courts to use a balancing test in determining whether jurisdiction over a nonresident violates due process." In World-Wide Volkswagen Corp. $v$. Woodson, ${ }^{5}$ however, the Court recently suggested that due process is provided only if persons can predict with some certainty where their conduct "will and will not render them hable to suit."6

Predictable results require fixed rules and principles that define the constitutional hmits of state long arm jurisdiction. ${ }^{7}$ This

326 U.S. 310 (1945).

${ }^{2} I d$. at 316 (minimum contacts requirement ensures that maintenance of the suit "does not offend 'traditional notions of fair play and substantial justice' ") (quoting Milliken v. Meyer, 311 U.S. 457, 463 (1940)).

${ }^{3} 326$ U.S. at 319 ("It is evident that the criteria by which we mark the boundary line between those activities which justify the subjection of a corporation to suit, and those which do not, cannot be simply mechanical or quantitative."). See also In-Flight Devices Corp. v. Van Dusen Air, Inc., 466 F.2d 220, 235-36 (6th Cir. 1972); Gray v. American Radiator \& Standard Sanitary Corp., 22 Ill. 2d 432, 440, 176 N.E.2d 761, 765 (1961).

- See text and notes at notes 21-28 infra.

- 444 U.S. 286 (1980).

- Id. at 297 ("The Due Process Clause, by ensuring the 'orderly administration of the laws,' gives a degree of predictability to the legal system that allows potential defendants to structure their primary conduct with some minimum assurance as to where that conduct will and will not render them liable to suit.") (quoting International Shoe Co. v. Washington, 326 U.S. 310, 319 (1945)). See also Louis, The Grasp of Long Arm Jurisdiction Finally Exceeds its Reach: A Comment on World-Wide Volkswagen Corp. v. Woodson and Rush v. Savchuk, 58 N.C.L. REv. 407, 430-32 (1980) (World-Wide rejected the traditional balancing approach in favor of a "bright line" test).

T The Supreme Court's inability to devise a set of rules for universal application is highlighted by the divisions on the Court in its recent decisions on the issue. Justice White wrote for the majority in World-Wide, yet he joined Justice Brennan's dissent in Kulko v. Superior Court, 436 U.S. 84, 101 (1978). Justice Marshall wrote the majority opinion in 
comment attempts to set forth such a set of principles to govern the exercise of long arm jurisdiction. ${ }^{8}$ Rejecting the balancing approach, it first outlines the three requirements that ensure adequate due process protection to nonresident defendants. These minimum requirements-causation, notice, and relevance-allow states wide latitude in asserting long arm jurisdiction. Using commercial cases as an illustration, the comment then considers additional limitations on long arm jurisdiction mandated by other provisions of the Constitution and necessary because of the nature of the defendant's underlying conduct.

\section{A Proposed Constitutional Framework for Jurisdictional ANALYSIS}

\section{A. Minimum Contacts and State Long Arm Statutes}

The due process clause permits a state to exercise jurisdiction only where "minimum contacts" exist between the defendant and the forum. "This requirement protects a defendant from "the burdens of litigating in a distant or inconvenient forum"10 by ensuring that it is "reasonable" to require him to defend the suit in the forum state." The minimum contacts rule also protects the "orderly administration of the laws"12 by preventing states from "reach[ing] out beyond the limits imposed on them by their status as coequal sovereigns in a federal system."1s

By enacting a long arm statute, a state exercises its constitutional prerogative to assert jurisdiction over nonresidents who have minimum contacts with it. These statutes provide for limited personal jurisdiction over nonresidents whose actions have caused injuries within the state. ${ }^{14}$ Jurisdiction is specific, ${ }^{15}$ extending only to

Kulko and dissented in World-Wide, 444 U.S. at 313. Justice Brennan dissented in both cases, 444 U.S. at 299; 436 U.S. at 101. Justice Powell was with the majority in World-Wide and the dissenters in Kulko, 436 U.S. at 101. Justice Blackmun was in the majority in Kulko and dissented in World-Wide, 444 U.S. at 313. Chief Justice Burger and Justices Stevens, Rehnquist, and Stewart voted with the majority in both cases.

- On the nature of long arm jurisdiction, see text and notes at notes 14-16 infra.

- See World-Wide Volkswagen Corp. v. Woodson, 444 U.S. 286, 291 (1980); Shaffer v. Heitner, 433 U.S. 186, 204 (1977) (minimum contacts analysis focuses on "the relationship among the defendant, the forum, and the litigation"); International Shoe Co. v. Washington, 326 U.S. 310, 316 (1945).

${ }^{10}$ World-Wide Volkswagen Corp. v. Woodson, 444 U.S. 286, 292 (1980).

${ }^{11}$ Id. (quoting Intermational Shoe Co. v. Washington, 326 U.S. 310, 317 (1945)).

12 International Shoe Co. v. Washington, 326 U.S. 310, 319 (1945).

1s World-Wide Volkswagen Corp. v. Woodson, 444 U.S. 286, 292 (1980).

14 Long arm statutes vary in breadth. The California statute, for example, provides that 
causes of action related to the in-state effects of a defendant's activities. $^{16}$

\section{B. A Balancing Test Versus Fixed Rules}

It generally is agreed that a state cannot assert jurisdiction over a nonresident defendant unless at least three conditions are satisfied: the defendant must have caused an effect in the forum, ${ }^{17}$ he must have had fair notice at the time of his act that it would cause an effect in the forum, ${ }^{18}$ and that effect must be related to

"[a] court of this state may exercise jurisdiction on any basis not mconsistent witb the Constitution of this state or of the United States." CaL. Crv. Proc. Code $\$ 410.10$ (West 1973). Statutes in most states are more restrictive, typically enumerating specific events and transactions-doing busimess in the state, committing a tort or causing a tortious effect in the stato, owning property in the state-and providing that causes of action arising from these acts support personal jurisdiction over nonresidents imvolved in them. See, e.g., N.Y. Crv. Prac. LAW $\S 302$ (McKinney 1972). In states that specify particular contacts, two questions must be answered when jurisdiction is asserted under a long arm statute: whether the contact falls within the scope of the statute, and if so, whether the state's exercise of jurisdiction is constitutional. F. JAMES \& G. HazArd, CrviL Procedoure $\$ 12.14$ (2d ed. 1977). The practical differences between the two approaches may be shigbt. The Minnesota statute specifies particular contacts, MinN. STAT. REv. $\S 543.19$ (West Supp. 1980), but bas been imterpreted "to assert in personam jurisdiction over nonresidents to the maximum extent consistent with due-process." Marquette Nat'l Bank v. Norris, 270 N.W.2d 290, 294 (Minn. 1978).

18 The rules and primciples outlined in this comment are irrelevant to determining whether a state may assert general jurisdiction over a defendant. In deciding this question, the court must examine the entire relationship between the defendant and the forum, not just the elements of that relationship connected to the particular cause of action. See von Mehren \& Trautman, Jurisdiction to Adjudicate: A Suggested Analysis, 79 Harv. L. REv. 1121, 1144-45 (1966).

${ }^{16}$ On the nature of long arm jurisdiction, see generally R. CRAMTON, D. CurRIE \& $H$. Kay, Conflict Of Laws: Cases-Comments-Questions 528-58 (2d ed. 1975); F. James \& G. Hazard, supra note 14, § 12.14; Restatement (Second) Of Conflict of Laws § 37 (1971) [hereinafter cited as Restatement]; $R$. Weintraub, Commentary on the Conplict of Laws \$§ 4.7-.21 (2d ed. 1980); Brilmayer, How Contacts Count: Due Process Limitations on State Court Jurisdiction, 1980 SuP. CT. REv. 77; Carrmgton \& Martin, Substantive Interests and the Jurisdiction of State Courts, 66 MrcH. L. REv. 227 (1967); Currie, The Growth of the Long Arm: Eight Years of Extended Jurisdiction in Illinois, 1963 U. ILL. L.F. 533; Woods, Pennoyer's Demise: Personal Jurisdiction After Shaffer and Kulko and a Modest Prediction on World-Wide Volkswagen Corp. v. Woodson, 20 ARIZ. L. REv. 861 (1978); Developments in the Law-State-Court Jurisdiction, 73 HARv. L. Rev. 909 (1960) [hereinafter cited as Developments]; Note, Long-Arm Jurisdiction in Commercial Litigation: When is a Contract a Contact?, 61 B.U.L. Rev. 375 (1981); Note, World-Wide Volkswagen Corp. v. Woodson: A Limit to the Expansion of Long-Arm Jurisdiction, 69 CALIF. L. REv. 611 (1981) [heremafter cited as California Note]; Comment, Federalism, Due Process and Minimum Contacts: World-Wide Volkswagen Corp. v. Woodson, 80 CoLum. L. Rev. 1341 (1980).

17 See text and notes at notes 48-66 infra.

18 See text and notes at notes $67-85$ infra. 
the cause of action. ${ }^{19} \mathrm{~A}$ few courts have viewed these three prerequisites as the only limitations on the reach of state long arm statutes. ${ }^{20}$

The consensus among courts ${ }^{21}$ and commentators, ${ }^{22}$ however, is that a balancing test should be used to determime whether a state may extend its long arm to a particular defendant. Typically, the defendant's interest in not being unfairly haled before a foreign court ${ }^{23}$ is balanced against the plaintiff's interest in his chosen forum, ${ }^{24}$ the judicial system's interest in having the suit tried in the forum state, ${ }^{25}$ and the forum's interest in asserting jurisdiction. ${ }^{28}$ Some advocates of balancing propose a two-step approach whereby a court first determmes whether a defendant knowingly caused a relevant event to occur within the forum; if lie did, the court then balances the factors outlined above to determine the "fairness" of asserting jurisdiction. ${ }^{27}$ Otliers propose forgoing the

10 See text and notes at notes 86-91 infra. The relevance requirement serves a purpose more akin to federalism than fairness, permitting jurisdiction only where an event gives the state a legitimate interest in the cause of action. See Woods, supra note 16, at 883; Comment, supra note 16 , at 1345-49. See also Brilmayer, supra note 16 , at 84 .

${ }^{20}$ See Pedi Bares, Inc. v. P\&C Food Mkts., Inc., 567 F.2d 933, 937 (10th Cir. 1977); Duple Motor Bodies, Ltd. v. Hollingsworth, 417 F.2d 231, 235 (9th Cir. 1969); Electro-Craft Corp. v. Maxwell Elecs. Corp., 417 F.2d 365, 368-69 (8th Cir. 1969). See also cases cited infra note 35 .

11 In addition to the Supreme Court cases cited at notes 23-26 infra, see, for example, Nova Biomedical Corp. v. Moller, 629 F.2d 190, 193 n.3 (1st Cir. 1980); Caesar's World, Inc. v. Spencer Foods, Inc., 498 F.2d 1176, 1180 (8th Cir. 1974); Wright v. Yackley, 459 F.2d 287, 290 n.7 (9th Cir. 1972); Chancellor v. Lawrence, 501 F. Supp. 997, 1001 (N.D. Ill. 1980); Blamey v. Brown, 270 N.W.2d 884, 887 (Minn.), cert. denied, 444 U.S. 1070 (1978).

${ }^{22}$ See, e.g., RestatemzNT, supra note 16, § 37 caveat a, para. 4 (1971); Carrington \& Martin, supra note 16, at 230-31; Woods, supra note 16, at 890-98; Developments, supra note 16, at 924-25.

2s This factor is "always a primary concern." World-Wide Volkswagen Corp. v. Woodson, 444 U.S. 286, 292 (1980).

24 See Kulko v. Superior Court, 436 U.S. 84, 92 (1978); Shaffer v. Heitner, 433 U.S. 186, 211 n.37 (1977). Some have suggested that jurisdiction may be asserted over a defendant with no forum contacts at all if the plaintiff has no alternative forum in which to sue the defendant. See Brilmayer, supra note 16, at 108-10; Woods, supra note 16, at 894; California Note, supra note 16 , at $629-30$.

2s See World-Wide Volkswagen Corp. v. Woodson, 444 U.S. 286, 292 (1980); International Shoe Co. v. Washington, 326 U.S. 310, 319 (1945) (court must balance "the quality and nature of the activity in relation to the fair and orderly administration of the laws which it was the purpose of the due process clause to insure"); Woods, supra note 16, at 893-94.

${ }^{26}$ See McGee v. International Life Ins. Co., 355 U.S. 220, 223 (1957); Carrington \& Martin, supra note 16, at 233-37; Woods, supra note 16, at 893; California Note, supra note 16, at 630; Comment, supra note 16, at 1345-49. See also cases discussed infra note 39.

${ }^{27}$ See, e.g., Bangor Punta Operations, Inc. v. Universal Mach. Co., 543 F.2d 1107, 1110 (5th Cir. 1976); Aanestad v. Beech Aircraft Corp., 521 F.2d 1298, 1300 (9th Cir.), cert. de- 
initial inquiry; once the court has determined that the defendant caused a relevant effect in the forum, it uses balancing alone to decide whether to assert jurisdiction. ${ }^{28}$

The balancing approach has two fundamental flaws. First, because it is unpredictable, it offers no guidance to persons seeking to avoid being subject to a state's jurisdiction. ${ }^{29}$ Each decision is too fact-bound for general apphication, and the weight given to each competing variable is left to the discretion of individual judges. Given this discretion, state courts often resolve close cases in their own favor, thereby steadily and inappropriately expanding jurisdiction..$^{30}$ Moreover, because the balancing approach considers factors the defendant can neither anticipate nor control, it is impossible for individuals to predict with any certainty where their conduct will render them subject to suit..11 For example, some

nied, 419 U.S. 998 (1974); Thorington v. Cash, 494 F.2d 582, 587 (5th Cir. 1974); Woods, supra note 16, at 862, 881-82; cf. REsTaTEMENT, supra note 16, $\$ 37$ caveat a (court should automatically assert jurisdiction if the defendant intentionally caused an effect in the forum, hut the balancing test applies if the defendant could only have reasonably anticipated that his conduct would affect the forum).

${ }^{28}$ See, e.g., Carrington \& Martin, supra note 16, at 230. Advocates of this approach have argued that in products hability actions, jurisdiction should be asserted over a inanufacturer even if he could not foresee the presence of his product in the forum. See Phillips v. Anchor Hocking Glass Corp., 100 Ariz. 251, 259-60, 413 P.2d 732, 737-38 (1966); Comment, In Personam Jurisdiction over Nonresident Manufacturers in Product Liability Actions, 63 Mich. L. REv. 1028, 1031-32 (1965).

${ }^{29}$ See World-Wide Volkswagen Corp. v. Woodson, 444 U.S. 286, 297 (1980) (due process "gives a degree of predictabihity to the legal system"). World-Wide seems to move away from traditional balancing because of its unpredictability. Although the Court acknowledged the competing variables in due process analysis, $i d$. at 292 , it focused on the defendant's contacts with the forum, finding "a total absence of those affiliating circumstances that are a necessary predicate to any exercise of state-court jurisdiction," id. at 295. Justice Brennan in dissent criticized the Court for not weighing other factors and noted that the Court previously had "declined to estabhsh a mechanical test based on the quantum of contacts between a State and the defendant . . . Id. at 300 (construing Kulko v. Superior Court, 436 U.S. 84, 92 (1978)). See generally Kennedy, Form and Substance in Private Law Adjudication, 89 HARv. L. REv. 1685, 1687-89 (1976) (distinguishing two different legal methods: the application of general rules, which has the advantage of certainty, and the use of an equitable standard to produce ad hoc decisions); Reese, Choice of Law: Rules or Approach, 57 CoRnELl L. REv. 315, 316 (1972) (contrasting rules, which provide certainty and predictability, with "approach," which weighs competing factors).

so Louis, supra note 6, at 430-32. But see Jay, Minimum Contacts As A Unified Theory of Personal Jurisdiction: A Reappraisal, 59 N.C.L. Rev. 429, 457-58 (1981) (state courts have exercised restraint in defining the proper reach of the long arm).

31 Even proponents of balancing adunit that predictability is impossible. California Note, supra note 16, at 630 ("One cannot deny that the balancing approach grants the courts a great deal of discretion. In addition, it creates a sizeable amount of uncertainty due to the inconsistencies that are hable to result from a court's balancing of various considerations."). 
courts have suggested considering the plaintiff's indigency and inability to travel to sue the defendant elsewhere. ${ }^{32}$ Because defendants cannot anticipate the wealth of potential plaintiffs, such equitable concerns undermine predictability.

The second flaw of the balancing approach is that the factors balanced have no constitutional relevance. A plaintiff's poverty, for example, has no apparent connection to the constitutional question of the defendant's amenabihty to suit. ${ }^{33}$ Similarly, variations on the reach of long arm jurisdiction that are based on the character of the defendant's conduct ${ }^{34}$ are inconsistent with principled due process analysis. Where a defendant's conduct is intentionally tortious or of httle social value, courts do not hesitate to assert jurisdiction if the minimum due process requirements of causation, notice, and relevance are met. ${ }^{35}$ Although protection of solne conduct might be compelled by other constitutional provisions, ${ }^{36}$ the due process clause alone does not support variations on jurisdiction

32 See, e.g., Phillips v. Anchor Hocking Glass Corp., 100 Ariz. 251, 260, 413 P.2d 732, 738 (1966).

s3 See Chancellor v. Lawrence, 501 F. Supp. 997, 1001 n.2 (N.D. Ill. 1980).

${ }^{34}$ Such variation is a common theme among courts and commentators. For example, the Supreme Court in Kulko v. Superior Court, 436 U.S. 84, 96 (1978), asserted that the "effects test" of the RESTATEMENT, supra note 16, $\$ 37$, might be apphicable when the defendant's conduct was commercial or tortious, but concluded that it was not applicable when the defendant's act was sending his daugbter to the forum state to live with her mother. See Note, Fairness or Federalism in Supreme Court Minimum Contact Analysis?: World-Wide Volkswagen Corp. v. Woodson, 37 WAsh. \& LEE L. REv. 1341, 1354 (1980) (Kulko was concerned with the nature and quality of the defendant's activity). See also Davis v. St. PaulMercury Indem. Co., 294 F.2d 641, 649 (4th Cir. 1961); Hunt v. Nevada State Bank, 285 Minn. 77, 110-12, 172 N.W.2d 292, 311-12 (1969) (extent of required contacts varies among libel, tort, and contract actions), cert. denied, 397 U.S. 1010 (1970); State ex rel. Sperandio v. Clymer, 581 S.W.2d 377, 382 \& n.5 (Mo. 1979) ("effects test" is apphicable only when a defendant's underlying activity was wrongful); Carrington \& Martin, supra note 16, at 23334, 240-42 (proper reach of long arm should be determined in part by the value of the defendant's underlying conduct); Reese \& Galston, Doing an Act or Causing Consequences as Bases of Judicial Jurisdiction, 44 IowA L. REv. 249, 262-63 (1959) (long arm should extend most extensively where a defendant's underlying activity is inherently dangerous).

ss See, e.g., Ohio v. Wyandotte Chemicals Corp., 401 U.S. 493, 500-01 (1971) (dictum) (state court would have jurisdiction over foreign polluter whose emissions affected state); Bangor Punta Operations, Inc. v. Universal Mach. Co., 543 F.2d 1107, 1110 (5th Cir. 1976); Thorington v. Cash, 494 F.2d 582, 587 (5th Cir. 1974) (if defendant intentionally sent false and misleading information into the forum, jurisdiction may be asserted without further analysis); Gemini Enterprises, Inc. v. WFMY Television Corp., 470 F. Supp. 559, 564 (M.D.N.C. 1979) (conspirater who knew, or should bave known, that coconspirator would commit conspiratorial acts in the forum is subject to its jurisdiction); J.E.M. Corp. v. McClellan, 462 F. Supp. 1246, 1255 (D. Kan. 1978) (alleged inisrepresentation in long-distance telephone call into state subjects caller to the state's jurisdiction).

se See text and notes at notes $46-47,92-116$ infra. 
that depend on the perceived social utihity of the defendant's activities.

Considerations of general convenience-the plaintiff's, the defendant's, and the judicial system's-also lack constitutional foundation. Such considerations are instead the cornerstone of the discretionary doctrine of forum non conveniens, which is unrelated to a forum's power over a defendant. . $^{37}$

The weight of the forum's interest in asserting jurisdiction also is irrelevant to its power to do so. Within constitutional bounds, a state legislature has the right to decide which actions causing instate effects it wishes to regulate in its courts. ${ }^{88}$ When a court restricts the reach of a state's long arm statute on the ground that the state has an insufficient interest in asserting jurisdiction, ${ }^{39}$ it usurps that right by substituting its judgment for that of the state's legislature.

Finally, the factor most commonly invoked in balancing analyses-a state's interest in providing its own residents with a forum $^{40}$-is also of doubtful constitutional legitimacy. The privileges and immunities clause of article $\mathrm{IV}^{41}$ prohibits state discrimination against the citizens of other states. Jurisdictional pohcies that favor residents arguably constitute just such forbidden discrimination. ${ }^{42}$

37 Under this doctrine, dismissal is appropriate when the suit may be brought in another forum, and either tbe defendant's convenience far outweighs that of the plaintiff or "trial in the chosen forum [is] inappropriate because of considerations affecting the court's own administrative and legal problems." Koster v. Lumbermens Mut. Cas. Co., 330 U.S. 518,524 (1947). Tbe doctrine applies only where jurisdiction and venue are proper in the original forum. See generally F. JAMES \& G. HAZARD, supra note 14, § 12.29; RESTATEMENT, supra note $16, \S 84$.

${ }^{38}$ See Owens v. Superior Court, 52 Cal. 2d 822, 831-32, 345 P.2d 921, 925 (1959); Nelson v. Miller, 11 Ill. 2d 378, 387, 143 N.E.2d 673, 678 (1957).

s9 See, e.g., Wright v. Yackley, 459 F.2d 287, 291 (9th Cir. 1972) (denying jurisdiction over out-of-state physicians who rendered medical services because forum's interest in not deterring out-of-state physicians from providing care was greater than its interest in redressing injury); Associated Am. Artists, Inc. v. Brevard Community College, 508 F. Supp. 292, 294 (S.D.N.Y. 1981) (denying jurisdiction over defendant who rented goods from resident plaintiff in part because of forum's interest in not deterring persons from dealing with New York businesses).

to See Caesar's World, Inc. v. Spencer Foods, Inc., 498 F.2d 1176, 1180 (8th Cir. 1974); California Note, supra note 16, at 626, 630; Comment, supra note 16, at 1346.

11 U.S. CoNST. art. IV, $\S 2$, cl. 1 ("The Citizens of each State sball be entitled to all Privileges and Immunities of Citizens in the several States.").

42 See, e.g., Corfield v. Coryell, 6 F. Cas. 546, 551-52 (C.C.E.D. Pa. 1823) (No. 3230) (access to other states' courts is protected by the privileges and immunities clause); Simson, Discrimination Against Nonresidents and the Privileges and Immunities Clause of Article IV, 128 U. PA. L. REv. 379, 398-99 (1979). See also Brilmayer, supra note 16, at 107. 
If the purpose of due process protection is to ensure that persons can avoid suits in foreign states, ${ }^{43}$ unpredictable and nonconstitutionally-based balancing tests should be rejected. Due process analysis should be governed instead by a body of fixed rules. Part II outlines a uniform body of rules governing causation, notice, and relevance that defines the extent of an individual's protection from a foreign state's authority and, by implication, the extent to which a state can protect itself from foreign individuals' acts that will affect it. Further restrictions on jurisdiction are legitimate only when there is a separate constitutional limitation on the state's power to regulate the defendant's underlying conduct.

This analysis still requires that courts consider the nature of the defendants' activities, ${ }^{44}$ but it provides a constitutional basis for doing so. Thus, additional restraints imposed in commercial cases, for exainple, should not be based on fairness to the defendant, $^{45}$ for he had the opportunity to protect limiself from the au-

4s World-Wide Volkswagen Corp. v. Woodson, 444 U.S. 286, 297 (1980). Professor Martin Redish has offered an alternative interpretation of the purpose of due process safeguards, arguing that "the only concern of a principled due process jurisdictional analysis should be the avoidance of inconvenience to the defendant." Redish, Due Process, Federalism, and Personal Jurisdiction: A Theoretical Evaluation, 75 Nw. U.L. REv. 1112, 1137 (1981).

Redish's analysis goes both too far and not far enougb. If he is correct, the fifth amendment's due process clause shonld limit federal jurisdiction to forums convenient for the defendant, and the fourteenth amendment's due process clause should limit state jurisdiction over its residents to convenient localities within the state. Yet Congress bas authorized nationwide service of process for certain actions in the federal courte, e.g., 28 U.S.C. \& 1335 (1976) (interpleader), and the Supreme Court in dictum noted Congress's power to do so in Mississippi Publishing Corp. v. Murphree, 326 U.S. 438, 442 (1946). Moreover, no court has ever read the fourteenth amendment's due process clause as prohibiting a state from forcing its residents to litigate in an inconvenient state court. See R. WRINTrAUB, supra note 16, \& 4.7, at 17-18 ("Within the state . . . there is, so far as due process is concerned, statewide jurisdiction once the required state nexus is found."). See also Aguchak v. Montgomery Ward Co., 520 P.2d 1352 (Alaska 1974). Furthermore, the due process clause is not concerned solely with convenience. As the Court noted in World-Wide, even where it is convenient for a defendant to litigate in a foreign forum, a state cannot assert jurisdiction over him if he has no contacts with it. 444 U.S. at 294.

The principle of jurisdictional due process proposed here preserves the territorial jurisdiction rule of Pennoyer v. Neff, 95 U.S. 714 (1878). Under the proposed primciple, a person can avoid a foreigu state's jurisdiction by forgoing acts that he anticipates will cause an effect tbere. The principle also preserves for states the power, recognized in Hess v. Pawloski, 274 U.S. 352 (1927), to require persons who knowingly cause effects in the state to consent to amenability to suit for those acts.

4 For courts that have done so, see cases cited supra note 34 .

4s See, e.g., Lakeside Bridge \& Steel Co. v. Mountain State Constr. Co., 597 F.2d 596, 603 n.12 (7th Cir. 1979) (possibility of discouraging interstate transactions underscores unfairness of asserting jurisdiction over out-of-state defendant who has only attenuated contractual links with forum), cert. denied, 445 U.S. 907 (1980). 
thority of the foreign state; nor should the restraints be based on the forum state's lack of interest in asserting jurisdiction over the defendant, ${ }^{4 \mathfrak{B}}$ for there are many reasons why a state might want to regulate commercial conduct that affects it. Rather, the restrictions should be justified by constitutional limitations on a state's power to regulate interstate commerce. ${ }^{47}$ Rules implementing this analysis are developed in part III.

This approach-fixing uniform minimum due process requirements and adding to them only where required by other constitutional provisions-serves several important purposes. It ensures that state jurisdiction is limited only by the Constitution's restrictions, subject to which a state should be free to regulate in its courts whatever foreign acts it wishes. Moreover, it preserves a uniform body of due process standards, thereby facilitating predictability of results; at the saine time, it provides jurisdictional rules that are fiexible in their apphication.

\section{Due Process Requirements: Causation, Notice, and Relevance}

\section{A. Causation}

Due process requires that a nonresident defendant have caused an effect in the forum state before the state may assert jurisdiction over him. ${ }^{48}$ Causation is less a definable phenomenon than a label attached to an aggregation of common sense notions.

18 See cases cited supra note 39.

47 U.S. CoNST. art. I, \& 8, cl. 3 authorizes Congress "[t]o regulate Commerce with foreign Nations, and among the several States . ..." On the nature of negative commerce clause analysis, see text and notes at notes 94-96 infra.

48 Restatement, supra note $16, \S 37$ ("A state has power to exercise judicial jurisdiction over an individual who causes effects in the state by an act done elsewhere with respect to causes of action arising from these effects . . . ."). See Reese \& Galston, supra note 34, at 260-63.

An intriguing conceptual question, albeit one that rarely arises in practice, is whether the defendant can be held responsible for an event caused by his failure to act. In Jahner $\mathrm{v}$. Jacob, 252 N.W.2d 1, 8 (N.D. 1977), the court held that the due process causation requirement is satisfied only by a voluntary act. Jurisdiction therefore could not be asserted over two defendants who had received misappropriated property mailed from North Dakota, because no voluntary act tied them to the misappropriation or to the mailing.

Although the result in Jahner may be correct, the court stated the governing primciple too broadly. If a defendant realized that his failure to act would cause an event, and if he was able to prevent the occurrence of that event, he bad an opportunity to avoid being liable to suit in the forum state. Therefore, the state could fairly assert jurisdiction over him. The real problem is determining when a state may impose a duty to act on out-ofstaters. 
Typical examples include a defendant shooting someone in the forum state while standing in an adjacent state ${ }^{49}$ and a defendant sending an injurious product into the state. ${ }^{.0}$

Most difficulties in estabhishing causation arise when the defendant did not cause the effect directly. There is no conceptual difficulty with attributing another person's actions to the defendant if he actually or constructively requested them and they are to his benefit. Thus, for jurisdictional purposes, a conspirator's actions are attributed to his coconspirators, ${ }^{51}$ an agent's actions are attributed to his principal, ${ }^{52}$ and a party's contractual performance

49 See RestaTEMENT, supra note $16, \S 37$ caveat a, para. 3.

so See, e.g., Gray v. American Radiator \& Standard Sanitary Corp., 22 Ill. 2d 432, 176 N.E.2d 761 (1961). Causation is not always so straightforward. Consider Block Indus. v. DHJ Indus., Inc., 495 F.2d 256 (8th Cir. 1974), a products liability action in which the defendant filed third-party complaints against the four fabric manufacturers from whom it had purchased fabric resembling the material that went into the plaintiff's shirt. The record sliowed only that the injurious fabric had come from one of the defendants, but not which one. Jurisdiction therefore was denied over all four because no single defendant had been connected to the plaintiff's injury.

${ }^{81}$ See, e.g., Leasco Data Processing Equip. Corp. v. Maxwell, 468 F.2d 1326, 1342-44 (2d Cir. 1972); Dixon v. Mack 507 F. Supp. 345, 352 (S.D.N.Y. 1980); Gemini Enterprises, Inc. v. WFMY Television Corp., 470 F. Supp. 559, 564 (M.D.N.C. 1979); McLaughlin v. Copeland, 435 F. Supp. 513, 529-32 (D. Md. 1977); Mandelkorn v. Patrick, 359 F. Supp. 692 , 696 (D.D.C. 1973). But see I.S. Joseph Co. v. Mannesmann Pipe \& Steel Corp., 408 F. Supp. 1023, 1024 (D. Minn. 1976) (antitrust venue case rejecting conspiracy theory).

The reluctance to assert jurisdiction in cases of alleged conspiracy results largely from fear that plaintiffs will use cursory allegations of conspiracy to drag defendants into inconvenient forums. See Kipperman v. McCone, 422 F. Supp. 860, 873 n.14 (N.D. Cal. 1976). Casad, Long Arm and Convenient Forum, 20 KAN. L. REv. 1, 19-20 (1971), suggests treating the problem as one of proof: if the plaintiff alleges enough to show that lie lias a good chance of proving conspiracy, the court should assert jurisdiction. This advice was followed in Professional Investors Life Ins. Co. v. Roussel, 445 F. Supp. 687, 696-97 (D. Kan. 1978) (noting that suit would be dismissed if subsequent discovery did not support the allegations). Cf. Glaros v. Perse, 628 F.2d 679, 682 (1st Cir. 1980) (no jurisdiction on conspiracy theory where plaintiff's allegations are imprecise and unsupported).

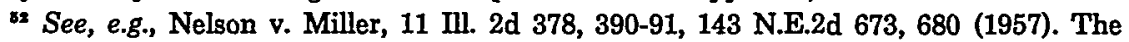
defendant is not subject to the forum's jurisdiction, however, if his agent caused the injury while acting outside the scope of the agency. See, e.g., Haker v. Southwestern Ry., 176 Mont. 364, 374, 578 P.2d 724, 728-29 (1978). It is unsettled whether jurisdiction over the defendant may be based on anotlier's act in the forum wliere the defendant subsequently ratified that act. Compare Plaza Realty Investors Co. v. Bailey, 484 F. Supp. 335, 346-48 (S.D.N.Y. 1979) (ratification insufficient) with State ex rel. Farmland Indus. Inc. v. Elliott, 560 S.W.2d 60, 63 (Mo. 1977) (ratification sufficient).

The defendant can be deemed jurisdictionally responsible for another's act even though no formal agency relationship exists between the two. All that usually is required is that the defendant have requested the act and that it be for his benefit. See Galgay v. Bulletin Co., 504 F.2d 1062, 1064-65 (2d Cir. 1974) (New York long arm statute does not require formal agency relationship to impute activity in forum state to out-of-state defendant); Barer v. Goldberg, 20 Wash. App. 472, 478-81, 582 P.2d 808, 872-73 (1978) (husband's in-state ac- 


\section{may be imputed to another party to the contract. ${ }^{.3}$}

Most courts also recognize that the causation requirement is satisfied when an independent actor transmits the effects of the defendant's actions to the forum. ${ }^{54}$ Many commentators ${ }^{55}$ and courts, ${ }^{58}$ however, have asserted that this principle should not ex-

tions for benefit of the marriage are grounds for asserting jurisdiction over wife). It therefore has been held that a corporate agent was an agent of the defendant corporate officer when the agent's acts were requested by the officer and they inured to his benefit and not to the corporation's. United States v. Montreal Trust Co., 358 F.2d 239, 243 (2d Cir.), cert. denied, 384 U.S. 919 (1966); cf. Thames v. Gunter-Dunn Inc., 373 So. 2d 640, 642 (Ala. 1979) (acts of corporate agent not imputed to corporate officer who requested them when acts were to the benefit of the corporation). Similarly, a corporate subsidiary will be deemed an agent of its parent if the subsidiary acts at the behest of the parent and for its benefit. E.g., Finance Co. of Am. v. BankAmerica Corp., 493 F. Supp. 895, 907 (D. Md. 1980). Cf. Biltmoor Moving \& Storage Co. v. Shell Oil Co., 606 F.2d 202, 207-08 (7th Cir. 1979) (defendant general contractor subject to suit in forum because of independent subcontractor's performance there).

s3 See, e.g., Biltmoor Moving \& Storage Co. v. Shell Oil Co., 606 F.2d 202, 206-08 (7th Cir. 1979).

See Reese \& Galston, supra note 34, at 262. The Supreme Court implicitly endorsed this principle when it cited Gray v. American Radiator \& Standard Samitary Corp., 22 Ill. 2d 432, 176 N.E.2d 761 (1961), with approval in World-Wide Volkswagen Corp. v. Woodson, 444 U.S. 286, 298 (1980). In Gray, the Illinois Supreme Court upleeld jurisdiction over an out-of-state manufacturer even though its product had been brought into the forum by a purchaser who was not under the control of the manufacturer. 22 Ill. 2 d at 442, 176 N.E.2d at 766. See also Hapner v. Rolf Brauchli, Inc., 404 Mich. 160, 177, 273 N.W.2d 822, 827 (1978) (Moody, J., dissenting).

Some courts have argued to the contrary. See, e.g., W.G. Bush \& Co. v. Sioux City \& New Orleans Barge Lines, 474 F. Supp. 537, 543 (M.D. Tenn. 1977) (repair company had no control over eventual location of repaired barge); Louis Marx \& Co. v. Fuji Seiko Co., 453 F. Supp. 385, 390-91 (S.D.N.Y. 1978) (defendant had no control over putative agent); Mueller v. Steelcase, Inc., 172 F. Supp. 416, 419 (D. Minn. 1959) (manufacturer had no control over location of product). The notice requirement, however, protects against any unfairness in asserting jurisdiction when the effect is transmitted by a third party. See text and notes at notes 67-69 infra.

${ }^{85}$ See, e.g., Brilmayer, supra note 16, at 93-94; Currie, supra note 16, at 555-56; Woods, supra note 16 , at $891-92$.

so For example, several courts have held that a merchant is not responsible for the presence of his product in the forum when it was the plaintiff who took it there. See, e.g., Mueller v. Steelcase, Inc., 172 F. Supp. 416, 419 (D. Minn. 1959); Dunn v. Upjohn Co., 350 So. 2d 127, 129 (Fla. Dist. Ct. App. 1977). Cf. Craig v. General Finance Corp., 504 F. Supp. 1033 (D. Md. 1980) (no jurisdiction over defendant in defamation action where plamtiff moved to forum and defendant attempted to collect preexisting debt by informing plaimtiff's new employer of the debt). But cf. Lachman v. Bank of La., 510 F. Supp. 753, 757 (N.D. Ohio 1981) (jurisdiction asserted over defendant credit card company because it permitted plaintiff to continue using card after he moved to the forum).

Numerous courts have refused to assert jurisdiction over out-of-state plyysicians whose contacts with the forum were limited to treatment of travelling patients who resided in the forum. See, e.g., Wright v. Yackley, 459 F.2d 287, 291 (9th Cir. 1972); Chancellor v. Lawrence, 501 F. Supp. 997, 1001-02 (N.D. Ill. 1980); Jackson v. Wileman, 468 F. Supp. 822, 82425 (W.D. Ky. 1979); Woodward v. Keenan, 79 Mich. App. 543, 547-48, 261 N.W.2d 80, 82-83 (1977) (per curiam). 
tend to situations where that actor is the plaintiff. ${ }^{57}$ It might be argued that two recent Supreme Court decisions support this restrictive causal approach. In Kulko v. Superior Court, ${ }^{\text {s8 }}$ the Court held that California could not assert jurisdiction in an action for child support over a New York father who had allowed his daughter to go to Califorina to hive with her mother. ${ }^{58}$ In World-Wide Volkswagen Corp. v. Woodson, ${ }^{\text {Bo }}$ the Court held that Oklahoma could not assert jurisdiction in a products hability action over a New York automobile dealer when the plaintiff bought a car in New York and was injured in Oklahoma. ${ }^{\text {.1 }}$ Although neither opinion invoked the rationale that the plaintiff created the contact, both opinions suggest that the Court thougbt it relevant that the plaintiff had transmitted the effect of the defendant's out-of-state

Similarly, courts have commonly held that a defendant may not be sued in the forum merely because the plaintiff's business suffered economic loss there as a result of the defendant's conduct elsewhere. They reason that the defendant's acts had an effect in the forum only because the plaintiff chose to locate its business there. See, e.g., Friedr. Zoellner Corp. v. Texas Metals Co., 396 F.2d 300, 303 (2d Cir. 1968) (construing New York statute); American Eutectic.Welding Alloys Sales Co. v. Dytron Alloys Corp., 439 F.2d 428, 433 (2d Cir. 1971) (same). Cf. Hilferty v. Neesan, 506 F. Supp. 218, 220 (E.D. Pa. 1980) (no jurisdiction where the only events in the forum were plaintiff's residual pain and suffering for injury incurred elsewhere); Leaks v. Ex-Lax, Inc., 424 F. Supp. 413, 415-17 (D.D.C. 1976) (same).

It also has been held that a buyer is not subject to suit in the seller's home state where his contacts with the forum were induced by the seller's advertising in the buyer's state. See, e.g., Conn v. Whitmore, 9 Utah 2d 250, 254-55, 342 P.2d 871, 874 (1959). Where the defendant is the siren, jurisdiction exists even where the plaintiff created the contact, because the defendant enticed him into doing just that. See Woodward v. Keenan, 79 Mich. App. 543, 548-50, 261 N.W.2d 80, 83 (1977) (subjecting doctors who advertise or solicit across state lines to long arm jurisdiction).

See also the New York courts' curious refusal to exercise jurisdiction over a defendant on the basis of his agent's activities in New York if tle agent is the plaintiff. Parke-Bernet Galleries, Inc. v. Franklyn, 26 N.Y.2d 13, 19 n.2, 256 N.E.2d 506, 509 n.2, 308 N.Y.S.2d 337, 341 n.2 (1970). For criticism of this doctrine, see Note, New York's Long-Arm Jurisdiction: The Case for the Agent-Plaintiff, 41 BrooktyN L. REv. 625, 657-64 (1975).

${ }^{37}$ This rule probably is based on vague notions of fairness and an unwillingness to hold the defendant responsible for the plaintiff's conduct. See Lakeside Bridge \& Steel Co. v. Mountain State Constr. Co., 597 F.2d 596, 602-03 (7th Cir. 1979), cert. denied, 445 U.S. 907 (1980). Similar concerns of fairness underlie the rule that a court should not exercise jurisdiction over a defendant who was tricked into the forum by the plaintiff, see, e.g., Wyman v. Newhouse, 93 F.2d 313 (2d Cir. 1937), cert. denied, 303 U.S. 664 (1938), and the rule that a court shonld not exercise in rem jurisdiction when the plaintiff brouglit the defendant's res into the forum to obtain jurisdiction over him, see, e.g., Abel v. Smith, $151 \mathrm{Va}$. 568, 577-79, 144 S.E. 616, 619 (Spec. Ct. App. 1928).

\footnotetext{
s8 436 U.S. 84 (1978).

s8 Id. at 86-90.

60444 U.S. 286 (1980).

1 Id. at 287.
} 
act to the forum state. ${ }^{62}$

From a causal standpoint, however, there is no principled justification for treating plaintiffs differently from other persons who transmit effects. To the extent that it might be unfair to assert jurisdiction, the requirement of fair notice, which ensures that the defendant had an opportunity to take precautions to avoid being subject to suit, ${ }^{63}$ assures sufficient protection. The fact that the plaintiff rather than the defendant or a third party created the contact is irrelevant to the defendant's ability to take protective measures if he perceives the risk. ${ }^{64}$

Moreover, excluding plaintiff-created contacts can produce absurd results. In a recent Alaska products liability action, ${ }^{65}$ for example, the defendant, a local merchant, filed a third-party complaint against the out-of-state manufacturer of the injurious product. The manufacturer argued that it should not be subject to jurisdiction because the inerchant was responsible for the presence of the product in Alaska. Had that argument been accepted, the manufacturer would have been subject to jurisdiction if the original plaintiff sued it directly, because the effect was transmitted by the middleman merchant; the manufacturer would not have been amenable to suit there if the local merchant sought to impose the same liability. ${ }^{60}$

${ }^{62}$ In Kulko, the Court stated:

Finally, basic considerations of fairness point decisively in favor of appellant's State of domicile as the proper forum for adjudication of this case, whatever the merits of appellee's underlying claim. It is appellant who has remained in the State of the inarital domicile, whereas it is appellee who has moved across the contiment.

436 U.S. at 97. In World-Wide, the Court stated that "[i]t is foreseeable that the purchasers of automobiles sold by [the defendants] may take them to Oklahoma. But the mere 'unilateral activity of those who claim some relationship with a nonresident defendant cannot satisfy the requirement of a contact with the forum State." " 444 U.S. at 298 (quoting Hanson v. Denckla, 357 U.S. 235, 253 (1958)). Hanson does not support the rule discussed here, however. In that case, it was the testator who created the defendant trustee's contact with the forum state, not the plaintiff beneficiaries. 357 U.S. at 238-39.

${ }^{83}$ See text and notes at notes 67-69 infra.

- For example, the defendant in Kulko could have refused to permit his daughter to go to California. Similarly, if the defendants in World-Wide could have anticipated hability, they could have taken protective measures or simply refused to sell the automobile. Accord, Comment, supra note 16, at 1354-55.

os Volkswagenwerk, A.G. v. Klippan, GmbH, 611 P.2d 498 (Alaska), cert. denied, 449 U.S. 974 (1980).

Id. at 502 . 


\section{B. Notice}

Due process also requires that jurisdiction can be asserted only over a defendant who could anticipate, ${ }^{\text {ot }}$ or who had "fair notice," state. $^{6 \theta}$ Courts have struggled with two aspects of the notice requirement: first, of what it is that notice must be had, and second, whether the defendant must purposefully desire the contact with the forum state.

Prior to Kulko, it was thought that jurisdiction could be asserted if the defendant reasonably could have foreseen or anticipated that his actions would cause an effect in the forum..$^{70}$ In that case, however, the Supreme Court indicated that the defendant had to be able to anticipate "being 'haled before a [foreign] court." "71 Read literally, this language requires that a defendant be able to anticipate actually being sued in the forum because of the effect he caused there. ${ }^{72}$

6z There is some confusion as to whether the proper standard is foreseeability or anticipation. A number of courts employ the former term. E.g., Pedi Bares, Inc. v. P\&C Food Mkts., Inc., 567 F.2d 933, 937 (10th Cir. 1977); Buckeye Boiler Co. v. Superior Court, 71 Cal. 2d 893, 902, 458 P.2d 57, 64, 80 Cal. Rptr. 113, 120 (1969). The distinction between foreseeability and anticipation is probably purely semantic. If there is in fact a difference, however, the anticipation standard seems to have carried the day. See World-Wide Volkswagen Corp. v. Woodson, 444 U.S. 286, 295-97 (1980) ("foreseeability" of product's presence in foreign state insufficient; defendant must be able to "reasonably anticipate heing haled into court there"). See also Leasco Data Processing Equip. Corp. v. Maxwell, 468 F.2d 1326, 1341 (2d Cir. 1972) (Friendly, J.) ("foreseeability" too low a standard; defendant "must know, or have a good reason to know, that his conduct will have effects in the [forum] state").

cs See Woods, supra note 16, at 885-90. Justice Stevens introduced the term in his concurring opinion in Shaffer v. Heitner, 433 U.S. 186, 217-19 (1977) ("The Due Process Clause affords protection against 'judgments without notice.' . . The requirement of fair notice also, I beheve, includes fair warning that a particular activity may subject a person to the jurisdiction of a foreign sovereign.") (quoting International Shoe Co. v. Washington, 326 U.S. 310,324 (1945)).

Bo See World-Wide Volkswagen Corp. v. Woodson, 444 U.S. 286, $295-97$ (1986); Leasco Data Processing Corp. v. Maxwell, 468 F.2d 1326, 1341 (2d Cir. 1972); R. WeINTrauB, supra note $16, \S 4.16$, at $161-64$. See generally Woods, supra note 16 , at $883-89$. The standard is objective. See, e.g., Oswalt v. Scripto, Inc., 616 F.2d 191, 200-01 (5th Cir. 1980).

${ }^{70}$ See Restatement, supra note $16, \S 37$; R. WeInTRAUB, supra note $16, \S 4.16$, at 161 62 (foreseeability of consequence or harm in forum essential to satisfaction of due process requirements).

${ }^{71}$ Kulko v. Superior Court, 436 U.S. 84, $97-98$ (1977) (quoting Shaffer v. Heitner, 433 U.S. 186, 216 (1977)). This standard was reiterated in World-Wide Volkswagen Corp. v. Woodson, 444 U.S. 286, 297 (1980).

72 See, e.g., Kellan v. Holster, 518 F. Supp. 175, 178 (M.D. Fla. 1981). The rule has been criticized as circular: jurisdiction over the defendant depends on his foreknowledge of that jurisdiction. See, e.g., Jay, supra note 30 , at 443; California Note, supra note 16, at 621 . 
Although appropriate in commercial cases, ${ }^{78}$ and perhaps properly applied in Kulko itself, such a rule cannot serve as a general standard for determining jurisdiction. For example, where an out-of-state defendant intentionally injures someone in the forum, no court would refuse to assert jurisdiction merely because the defendant had reason to beheve the injury would not be discovered or that the victim would select a different forum in which to sue. ${ }^{74}$ Such a result could be avoided by interpreting Kulko to require anticipation of legal liability rather than actual suit on the basis of that liability. ${ }^{75}$ Even this rule would be too restrictive, however, for it would not permit a state to reach a defendant who caused a potentially (but not predictably) dangerous effect to occur within it. For example, where a nonresident defendant loaned his automobile to a friend who had an accident in the forum, ${ }^{76}$ a rule requiring anticipation of legal liability would deny a state jurisdiction over the defendant unless he could have "reasonably anticipated" the accident. Generally, it makes sense to define fair notice as anticipation of an effect rather than anticipation of legal liability. ${ }^{77}$

The fair notice requirement sometimes is made more stringent by requiring that the defendant liave acted "purposefully." The Supreme Court in Hanson v. Denckla ${ }^{78}$ so held, and the Court lias reaffirmed this rule consistently without ever defining it. ${ }^{79}$ It is un-

${ }^{23}$ See text and notes at notes 101, 107-115 infra.

${ }^{74}$ See note 35 supra.

${ }^{75}$ The Court in World-Wide seemed to equate the "haled into court" language with being "subject to suit." 444 U.S. 286, 297 (1980).

${ }^{76}$ It generally is agreed that jurisdiction exists in these circumstances. See Davis v. St. Paul Mercury Indem. Co., 294 F.2d 641, 643-48 (4th Cir. 1961); cf. Worthley v. Rockville Leasecar, Inc., 328 F. Supp. 185, 187-88 (D. Md. 1971) (airplane).

${ }^{77}$ In addition to consistency with precedent, see cases cited supra note 67, two other considerations support such a reading. First, the Court has never indicated either the genesis or the explanation for the supposed heightened standard. Second, the purpose of the due process standard set forth in World-Wide, to allow individuals "to structure their primary conduct with soine minimum assurance as to where [it] will and will not render them hable to suit," 444 U.S. at 297 , is fulfilled by the traditional, more expansive standard.

${ }^{78} 357$ U.S. 235, 253 (1968) (jurisdiction may be asserted over a defendant only if he "purposefully avails [him]self of the privilege of conducting activities within the forum state, thus invoking the benefits and protections of its laws").

79 See, e.g., Rush v. Savchuk, 444 U.S. 320, 329 (1980); World-Wide Volkswagen Corp. v. Woodson, 444 U.S. 286, 297 (1980); Shaffer v. Heitner, 433 U.S. 186, 216 (1977). It has heen suggested that the requirement should be ignored as careless dictum. See Phillips v. Anchor Hocking Glass Corp., 100 Ariz. 251, 256, 413 P.2d 732, 735 (1966); International Harvester Co. v. Hendrickson Mfg. Co., 249 Ark. 298, 301-03, 459 S.W.2d 62, 64-65 (1970). But see Comment, supra note 16, at 1355 (if "defendant has met the purposeful affiliation requirement of Hanson $v$. Denckla, it has fair notice"). 
clear whether it is the defendant's underlying act or the contact itself that must have been purposeful. Under the former approach, a defendant purposefully avails himself of a contact with the forum state as long as he had fair notice that his act would have an effect there. ${ }^{80}$ Under this definition, however, Kulko appears to be wrongly decided. Kulko certainly knew that his child would go to California, and he should not have been surprised that she took advantage of benefits provided by the state once she was there. Yet the Court concluded that Kulko's action was not purposeful. ${ }^{81}$ The case therefore suggests that the contact itself must be purposeful. Kulko's act was not purposeful because he neither desired his daughter's presence in California nor received any personal benefit from her presence there. ${ }^{82}$

This concept of purposefulness, emphasizing the contact rather than the act, has been used by lower courts to justify protection of local merchants who knowingly make sales to customers from other states, but who generally do httle business with persons from those states. ${ }^{83}$ Under this reasoning, a merchant who sells to an occasional nonresident customer may know that his product is going to a foreign state, but because his business does not depend on foreign sales, he has no interest in the product's presence there.

Although the purposefulness requirement seems to achieve the correct result in Kulko and the local merchant cases, jurisdictional

80 See Poyner v. Erma Werke GmbH, 618 F.2d 1186, 1191 (6th Cir. 1980) ("purposeful" if defendant knew his actions would have an effect in the forum state), cert. denied, 449 U.S. 841 (1981); King v. Hailey Chevrolet Co., 462 F.2d 63, 67 \& n.4, 68 (6th Cir. 1972) ("purposeful" if defendant could foresee that his actions would have an effect in the forum state).

In World-Wide, Justice White intimated that the point of the purposeful availment rule was to ensure that the defendant had fair notice that his act might render him hable to suit in the forum state: "When a corporation 'purposefully avails itself of the privilege of conducting activities within the forum State,' . . . it has clear notice that it is subject to suit there and can act to alleviate the risk of burdensome hitigation . . . " 444 U.S. at 297 (quoting Hanson v. Denckla, 357 U.S. 235, 253 (1968)). See also Woods, supra note 16, at 885.

81436 U.S. 84, 93-94 (1978). The Court emphasized that any benefits of California residency went to the child rather than her father and that Kulko did not purposefully seek any benefits from his daughter's contacts.

82 Id. at 94 n.7.

ss See, e.g., Khalaf v. Bankers \& Shippers Ins. Co., 404 Mich. 134, 156-57, 273 N.W.2d 811, 820-21 (1978) ("The generating cause is not the [defendant'8] desire to enlarge his business into Michigan, but, rather, the Michigan customer's desire to do business with the [defendant]. A localized business . . . does not depend on multi-state distribution to generate volume. Out-of-state effects are but an incident of the business."); State ex rel. Sperandio v. Clymer, 581 S.W.2d 377, 382-83 (Mo. 1979); Pellegrini v. Sachs \& Sons, 522 P.2d 704, 707 (Utah 1974). 
analysis under the due process clause should not turn on whether a defendant "consciously desires" the contacts created by his acts in addition to the acts themselves. Universal application of the rule would produce absurd results. Consider the case of a defendant who pollutes in one state knowing that the pollutants will be carried to the forum state. Although the Supreme Court has suggested that the forum state should have jurisdiction, ${ }^{84}$ it is unlikely that the polluter "consciously desires" the pollutants' presence in the forum; if the polluter has any desire regarding his effluents, it is probably that they vanish. ${ }^{85}$

\section{Relevance}

Due process also requires that a state may only assert long arm jurisdiction if the effect caused by the defendant is related to the cause of action..$^{86}$ Although easily grasped, the concept of a relevant event is difficult to articulate. ${ }^{87}$ Professor Lea Brilmayer has suggested a readily applicable test: an event is relevant for jurisdictional purposes if it is substantively relevant to the cause of action. ${ }^{88}$ This test is grounded on what most agree is the theoretical justification for the relevancy requirement: only a substantively relevant event gives the state a legitimate interest in adjudicating the controversy. ${ }^{89}$ It is difficult to imagine a situation where the state would have such an interest if a substantively relevant event had not occurred within its borders.90

s4 Ohio v. Wyandotte Chems. Corp., 401 U.S. 493, 500 (1971).

ss Although the purposefulness requirement is inappropriate as a general jurisdictional guide, part III argues that it is proper to focus on whether the defendant consciously sought some benefit from his contact with the forum in cases involving interstate commercial activity.

se The RESTATEMENT, supra note 16, combines relevance and causation: "A state has the power to exercise judicial jurisdiction over an individual who causes effects in the state by an act done elsewhere with respect to causes of action arising from these effects . . .." Id. $\S 37$ (emphasis added). See also Reese \& Galston, supra note 34, at 264.

87 The cases and the hiterature provide little guidance to distinguish relevant from irrelevant events. The RESTATEMENT, supra note $16, \S 37$, requires that the cause of action "arise from" the effects of the defendant's actions in the forum state, without explaining what that means. von Mehren and Trautman, supra note 15, at 1144-45, merely state that the cause of action must "arise out of" or be "intimately related to" the defendant's contacts with the forum state.

${ }^{83}$ Brilmayer, supra note 16 , at 82.

89 See Jonnet v. Dollar Savings Bank, 530 F.2d 1123, 1140 (3d Cir. 1976) (Gibbons, J., concurring) (due process prevents state from asserting jurisdiction without a "palpable" interest in the controversy that is "rationally connected with forum policy"); Comment, supra note 16 , at $1345-49$.

${ }^{90}$ Brilmayer, supra note 16 , at $83-84$, cites only one lower court opinion in which a 
The suggested test is too broad, however, for not every substantively relevant event gives a state a legitimate interest in asserting jurisdiction over the defendant. Consider again Kulko. Although the Kulkos' marriage while on a California vacation may not have been a substantively relevant event in an action for child support, their daughter's conception there undeniably would be. Yet it would be tenuous to argue that California would have a "legitimate interest" in asserting jurisdiction over Kulko if his daughter had been conceived there during a brief vacation.

In most cases, intuition suffices to distinguish relevant from irrelevant events. For example, it seems obvious that Kulko's visits to California years before the child support action arose and his marriage to Mrs. Kulko during one of those visits could not provide California with jurisdiction over him.91 Although the Brilmayer proposal may be as close as one can come to a comprehensive test, it remains necessary to rely on intuition as a general guide.

\section{Additional Constitutional Requirements: Commercial CASES}

Constitutional restrictions on the power of states to regulate certain activities impose additional limitations on state long arm jurisdiction beyond the minimum due process requirements outlined in part II. For example, it has been suggested that the first amendment requires limitations on the long arm's reacl to avoid deterring newspapers from disseminating information in foreign states. ${ }^{92}$ Similarly, Kulko could be supported on the ground that

substantively irrelevant event has been held to support jurisdiction: Cornelison v. Chauney, 16 Cal. 3d 143, 545 P.2d 264, 127 Cal. Rptr. 352 (1976) (truck driver involved in an accident on his way to tbe forum state).

91 The majority opinion acknowledged this inadequacy. 436 U.S. at 92-93.

${ }^{92}$ See New York Times Co. v. Connor, 365 F.2d 567 (5th Cir. 1966), where the court refused to assert jurisdiction over the Times where it was alleged to have circulated defamatory articles in Mississippi and Alabama. Reasoning that "First Amendment considerations surrounding tbe law of libel require a greater showing of contact to satisfy the due process clause than is necessary in asserting jurisdiction over other types of activity," $i d$. at 572 , the court held that jurisdiction should only be asserted over an out-of-state newspaper if its circulation in the forum is sufficient to offset the risk of being subject to suit there. See also Buckley v. New York Post Corp., 373 F.2d 175 (2d Cir. 1967); Buckley v. New York Times Co., 338 F.2d 470, 475 (5tb Cir. 1964) (Brown, J., concurring in part and dissenting in part); Carrington \& Martin, supra note 16, at 240-43. But see Church of Scientology v. Adams, 584 F.2d 893, 899 (9th Cir. 1978); Anselmi v. Denver Post, Inc., 552 F.2d 316, 324 (10th Cir.), cert. denied, 432 U.S. 911 (1977); Curtis Publishing Co. v. Golino, 383 F.2d 586 (5th Cir. 1967) (asserting jurisdiction over out-of-state magazine publisher); Comment, Constitu- 
the Constitution himits a state's regulatory power over family matters. ${ }^{93}$ These explanations rest on the premise that in areas where the Constitution limits the states' regulatory power, the reach of long arm jurisdiction should be concomitantly limited so that it will not impinge unduly on the protected conduct. In the context of commercial transactions, this part explores the constitutional justifications for stricter limits on jurisdiction and proposes additional rules that serve these purposes.

\section{A. Rules Based on the Commerce Clause}

The commerce clause ${ }^{94}$ requires courts to invalidate state laws that unreasonably impair interstate commerce. ${ }^{95}$ Thus, a state's ability to assert jurisdiction over nonresidents who have commercial contacts with its citizens is constrained by "the national interest in keeping interstate commerce free from interferences which seriously impede it." ${ }^{\prime \prime 6}$ Jurisdictional standards may impair commerce in two ways. First, the threat of hability to suit in a foreign jurisdiction discourages transactions with foreseeable foreign effects. ${ }^{97}$ Second, assertion of long arm jurisdiction may frustrate the

tional Limitations to Long Arm Jurisdiction in Newspaper Libel Cases, 34 U. CHI. L. REv. 436 (1967).

${ }^{83}$ Although there is no clear support for such a proposition in the Constitution, several Supreme Court decisions have held that the Constitution limits the power of a state to intrude in family affairs. See, e.g., Moore v. City of E. Cleveland, 431 U.S. 494, 499 (1977) (striking down zoning ordinance limiting occupancy to a single family because it infringed on "freedom of personal choice in matters of marriage and family he" without a compelling justification); Roe v. Wade, 410 U.S. 113 (1973) (right to abortion); Griswold v. Connecticut, 381 U.S. 113 (1965) (right to use contraception). See generally Developments in the Law-The Constitution and the Family, 93 HARv. L. REv. 1156 (1980). At the least, Kulko clearly stands for the proposition that family concerns deserve special consideration in due process analysis. Accord, Demarest v. Superior Court, 103 Cal. App. 3d 791, 798, 165 Cal. Rptr. 641, 644 (1980).

*4 U.S. Const. art. I, \& 8, cl. 3. See note 47 supra.

is The Supreme Court has described the nature of the "dormant commerce clause" thus:

For a hundred years it has been accepted constitutional doctrine that the commerce clause, without the aid of Congressional legislation, thus affords some protection from state legislation inimical to the national commerce, and that in such cases, where Congress has not acted, this Court, and not the state legislature, is under the commerce clause the final arbiter of the competing demands of state and national interests.

Southern Pac. Co. v. Arizona, 325 U.S. 761, 769 (1945). See also Raymond Motor Transp., Inc. v. Rice, 434 U.S. 429 (1978) (state highway regulations); Bibb v. Navajo Freight Lines, Inc., 359 U.S. 520 (1959) (state highway regulations); Dean Milk Co. v. Madison, 340 U.S. 349 (1951) (access of foreign sellers to local markets).

${ }^{28}$ Southern Pac. Co. v. Arizona, 325 U.S. 761, 775-76 (1945).

o7 See Erlanger Mills, Inc. v. Cohoes Fibre Mills, Inc., 239 F.2d 502, 507 (4th Cir. 1956) 
reasonable expectations of commercial actors, thereby decreasing commercial certainty. ${ }^{98}$ Although certainty and predictability are essential in commercial transactions, the permissible reach of long arm jurisdiction is least well defined in this context. ${ }^{99}$

The constitutional interest in facilitating interstate commerce seems to require additional jurisdictional limitations beyond the minimum safeguards of causation, notice, and relevance provided by due process. ${ }^{100}$ Jurisdiction slould not be asserted over a defen-

(Sobeloff, J.) (denying North Carohna jurisdiction over New York manufacturer who shipped goods to plaintiff in North Carohina):

[T]o sustain jurisdiction here . . . would involve the danger of grave burdens and impediments to interstate commerce, if the door should be opened to similar legislation by other States .... [L]et us consider the hesitancy a California dealer might feel if asked to sell a set of tires to a tourist with Pennsylvania license plates, knowing that he might be required to defend in the courts of Pennsylvania.a suit for refund of the purchase price or for leavy damages in case of accident attributed to a defect in the tires.

See also Wright v. Yackley, 459 F.2d 287, 291 (9th Cir. 1972) (limiting long arm so as not to deter out-of-state physicians from rendering medical services to residents); Associated Am. Artists, Inc. v. Brevard Community College, 508 F. Supp. 292, 294 (S.D.N.Y. 1981) (limiting long arm so as not to deter persons from dealing with forum merchants); Gelineau v. New York Univ. Hosp., 375 F. Supp. 661, 667-68 (D.N.J. 1974) (limiting long arm so as not to deter out-of-state physicians from rendering medical services to residents).

It lias been suggested, lowever, that limitations on the long arm cannot ease the overall deterrence to interstate transactions caused by potential jurisdictional costs, because protecting one party from hability to suit in lis opponent's preferred forum merely transfers the deterrent effect to the latter. See R. Cramton, D. CurRIE \& H. KaY, supra note 16, at 551. This criticism is flawed for two reasons. First, in many cases one party will be able to take protective measures without forgoing the transaction, while the other party will not. For example, if a mail order house cannot sue foreign purchasers in its loome forum, it will merely increase its insurance and raise prices; it will not abandon the mail order business. At best, then, the criticism is relevant only in those cases where neither party is able to take protective measures. Second, a person is more likely to be deterred by the risk of beimg sued in a distant forum than by the risk of having to travel to a distant forum to sue. In the latter situation, the person coufronted with the risk at least knows that the decision to bear the jurisdictional burden is in his own hands.

98 The jurisdictional rule offered here can be viewed as analogous to the damages rule of Hadley v. Baxendale, 9 Ex. 341, 156 E.R. 145 (1854): both limit legal liability to that which reasonably could have been anticipated by the defendant and so reduce commercial risk. Cf. C. McCormick, HandBooK on THE LAw of DAMAGes § 138 (1935) (discussing Hadley). Reducing commercial risk or nncertainty facilitates commerce. See, e.g., The Bremen v. Zapata Off-Slıore Co., 407 U.S. 1, 13-14 (1972). Cf. In-Fliglit Devices Corp. v. Van Dusen Air, Inc., 466 F.2d 220, 233-34 (6th Cir. 1972) (fairness requires the protection of the defendant's reasonable expectations).

92 Lakeside Bridge \& Steel Co. v. Mountain State Constr. Co., 445 U.S. 907, 911 (1980) (White, J., dissenting from denial of certiorari) (confusion of current jurisdictional standards "may well have a disruptive effect on commercial relations in which certainty of results is a prime objective").

100 Others have looked to the commerce clause and the federal interest in facilitating interstate commerce as grounds for limiting state long arm jurisdiction. See Carrington \& 
dant whose conduct is commercial in nature-that is, over one who puts a product into the stream of commerce or enters into a contract-unless the following two additional conditions are met. First, the defendant must have been able to anticipate that his conduct might lead to his being sued in the forum state. Second, in light of this perceived risk he must have had a reasonable opportunity to alter, without being forced to forgo, the conduct that caused the effect in the state. ${ }^{101}$

The Supreme Court has emphasized that the commerce clause does not prohibit imposition of burdens on nonresident commercial actors where they have an opportunity to pass the burdens along to residents. ${ }^{102}$ The proposed rules ensure that whenever a

Martin, supra note 16, at 234 (citing cases); Developments, supra note 16, at 983-87; Comment, supra note 16, at 1347-48 \& n.59. Cf. Horowitz, The Commerce Clause as a Limitation of State Choice-of-Law Doctrine, 84 HARv. L. REv. 806 (1971) (federal interest in facilitating interstate commerce should be a factor in choice of law decisions).

Prior to International Shoe Co. v. Washington, 326 U.S. 310 (1945), the commerce clause was occasionally invoked to deny states jurisdiction over foreign interstate carriers when the carriers had no lines and operated no service within the forum state, the cause of action arose outside the forum state, and the plaintiff did not live in the forum when the cause of action accrued. Denver \& R.G.W.R.R. v. Terte, 284 U.S. 284, 287 (1932); Davis v. Farmers Coop. Equity Co., 262 U.S. 312, 315 (1923). See Scanapico v. Richmond, F. \& P. Ry., 439 F.2d 17, 25-28 (2d Cir. 1970) (on reconsideration en banc) (Friendly, J.) (tracing history of commerce clause limitations on jurisdiction). Cf. F. JAMES \& G. HAZARD, supra note 14, § 12.27 (arguing that the cases "overlap and complement the broader and more flexible doctrine of forum non conveniens").

This dated line of precedent is inapplicable to the principle argued for here: that the commerce clause be used to deny a state jurisdiction even where the cause of action is related to the state. See Missouri ex rel. St. Louis, B. \& M. Ry. v. Taylor, 266 U.S. 200, 207 (1924) (Davis doctrine inapplicable when cause of action is related to the forum); Cardozo, The Reach of the Legislature and the Grasp of Jurisdiction, 43 CORNeLL L.Q. 210, 214 (1958).

${ }^{101}$ Since World-Wide Volkswagen Corp. v. Woodson, 444 U.S. 286 (1980), a few courts have held that jurisdiction may be asserted over a defendant who knew his actions might render him hable to suit in the forum and who had an opportunity to take protective measures in light of that risk. See, e.g., Plant Food Co-op v. Wolfkill Feed \& Fertilizer Corp., 633 F.2d 155, 159-60 (9tlı Cir. 1980); Puerto Rico v. The SS Zoe Colocotroni, 628 F.2d 652, 669-70 (1st Cir. 1980), cert. denied, 450 U.S. 912 (1981); Lachman v. Bank of La., 510 F. Supp. 753, 757 (N.D. Ohio 1981). In National Egg Co. v. Bank Leumi le-Israel B.M., 504 F. Supp. 305, 312 (N.D. Ga. 1980), however, the court thought it sufficient that the defendant could have avoided liability to suit in the forum by forgoing tbe transaction altogether. Requiring that the defendant rehinquish interstate activity to avoid jurisdictional hability would be impermissible under the rules developed in this comment.

${ }^{102}$ See General Trading Co. v. State Tax Comm., 322 U.S. 335, 338 (1944) (state use tax may be passed on). See also McGoldrick v. Berwind-White Coal Mining Co., 309 U.S. 33, 45-46 n.2 (1940) (recognizing the "danger that, to the extent that the burden falls on economic interests without the state, it is not likely to be alleviated by those pohitical restraints which are normally exerted on legislation where it affects adversely interests within the state"); Brilmayer, supra note 16, at 95-96 (arguing for restrictions on long arm jurisdic- 
state asserts jurisdiction over an outsider on the basis of a transaction with a resident, the outsider will have had an opportunity to pass the cost of jurisdictional liability on to the resident.

The first rule embraces in the limited commercial context the "anticipation of suit" standard rejected in its general application in part II-B. ${ }^{103}$ The second rule protects the same defendants as the "purposefully avails" standard rejected as a general jurisdictional guide; ${ }^{104}$ imposition of jurisdictional risks is likely to deter only those defendants who do not consciously seek benefits from their commerical contacts with foreign states. The rules provide a constitutional rationale for limiting jurisdiction where a commercial plaintiff acts unilaterally, without resorting to the artificial plaintiff-created contacts rule, ${ }^{105}$ and they justify protection of commercial activities without reliance on nonconstitutionallybased forum interest analyses. ${ }^{108}$

\section{B. Application of the Rules}

These rules explain a number of doctrines that courts have developed to himit the long arm in commercial cases. For example, the rules support the commonly accepted proposition that jurisdiction should not be asserted over an out-of-state merchant who only occasionally sells to residents of the forum state. ${ }^{107}$ The minimum due process requirements as formulated in part II pose no obstacle to jurisdiction if the local merchant has notice that his customer is an out-of-state resident, yet the merchant would not reasonably expect that the sale might lead to a suit against him in the buyer's home state; he is more hikely to view his customer's talk of a distant destination as pleasant conversation than as a warning of a potential inconvenient suit. Moreover, the merchant has no real opportunity to charge the occasional nonresident a higher price in hight of the unusual jurisdictional risks imposed by the transaction.

The rules also justify the courts' emphasis on the frequency, regularity, and nature of the commercial defendant's contacts with

tion over out-of-staters who have no opportunity to pass costs on to residents).

10 See text and notes at notes 71-77 supra.

104 See text and notes at notes 78-85 supra.

105 See text and notes at notes 55-66 supra.

106 See text and notes at notes 38-42 supra.

${ }^{107}$ See, e.g., World-Wide Volkswagen Corp. v. Woodson, 444 U.S. 286, 296 (1980) (rejecting foreseeability standard because it would subject local merchants-tire retailers and soft drink concessionaires- to the jurisdiction of foreign forums); Khalaf v. Bankers \& Shippers Ins. Co., 404 Mich. 134, 156-57, 273 N.W.2d 811, 820-21 (1978). 
the forum state. ${ }^{108}$ The existence of transactions between the defendant and forum residents besides the one at issue favors assertion of jurisdiction, because the defendant who regularly does business affecting the forum state has greater warning of the risk of being sued there and a better chance to alter his conduct in light of that risk. Similar considerations apply to firms engaged primarily in interstate business. ${ }^{109}$

The size of the transaction and the extent of the negotiations preceding it also are relevant in considering whether the commerce clause restricts the exercise of the long arm. ${ }^{110}$ The courts' concern with protecting passive purchasers is illustrative. ${ }^{111}$ A passive purchaser buys from a foreign seller's inventory at an unnegotiated price; ${ }^{112}$ almost by definition, he is unable to alter the terms of the transaction. Moreover, most transactions of this sort are so small that the purchaser has no incentive to diminish the risk of jurisdictional liability rather than simply forgo the transaction entirely. The transaction costs of, for example, procuring insurance, negotiating a forum selection clause, ${ }^{113}$ or altering the price to make acceptance of the risk palatable, are too great to make such restruc-

${ }^{108}$ See, e.g., Puerto Rico v. The SS Zoe Colocotroni, 628 F.2d 652, 668-70 (1st Cir. 1980), cert. denied, 450 U.S. 912 (1981); Standard Fittings Co. v. Sapag, S.A., 625 F.2d 630, 642 n.23 (5th Cir. 1980), cert. denied, 450 U.S. 918 (1981); Voorlas Mfg. Co. v. Mars Signal Light Co., 481 F. Supp. 828, 830 (E.D. Wis. 1979); Wisconsin Can Co. v. Banite, Inc., 88 F.R.D. 597, 600-01 (N.D. Ill. 1980); Buckeye Boiler Co. v. Superior Court, 71 Cal. 2d 893, 904-06, 458 P.2d 57, 65-66, 80 Cal. Rptr. 113, 121-22 (1969).

${ }^{109}$ von Mehren \& Trautman, supra note 15, at 1167-68.

110 See, e.g., In-Flight Devices Corp. v. Van Dusen Air, Inc., 466 F.2d 220, 233 (6th Cir. 1972); Galaxy Int'l, Inc. v. White Stores, Inc., 88 F.R.D. 311, 321-22 (W.D. Pa. 1980); Communication Equip. \& Contracting Co. v. Anchorage, 498 F. Supp. 632, 634 (M.D. Ala. 1980); Controlled Metals, Inc. v. Non-Ferrous Int'l Corp., 410 F. Supp. 339, 343 (E.D. Pa. 1976).

${ }^{111}$ See, e.g., Whittaker Corp. v. United Aircraft Corp., 482 F.2d 1079, 1084, 1085 (1st Cir. 1973); Architectural Bldg. Components Corp. v. Comfort, 528 P.2d 307, 310 (Okla. 1974).

${ }^{112}$ See In-Flight Devices Corp. v. Van Dusen Air, Inc., 466 F.2d 220, 233 (6th Cir. 1972) ("The buyer . . . is frequently a relatively passive party, simply placing an order, accepting the seller's price and terms as stated in his product advertising and agreeing only to pay a sum upon receipt of the goods or services."). Mail order consumers are a typical example. See Yankee Metal Prods. Co. v. District Court, 528 P.2d 311, 313 (Okla. 1974) (active/passive purchaser distinction "has the effect of protecting the ordinary 'mail order catalogne' consumer who merely orders a stock item of merchandise from a distant state, from the jurisdiction of the courts of the distant state").

11 s The Supreme Court upheld the validity of such clauses in National Equip. Rental, Ltd. v. Szukhert, 375 U.S. 311 (1964). See also The Bremen v. Zapata Off-Shore Co., 407 U.S. 1 (1972). 
turing worthwhile. ${ }^{114}$ The long arm therefore must be restricted in such cases.

On the other hand, when a transaction is for a large amount or is preceded by lengthy negotiations, the transaction costs of reducing the risk of hability by acquiring insurance or altering the terms of the bargam become reasonable. Moreover, the more significant the transaction is, the more hikely it is tbat the parties anticipated unusual costs; in the absence of a forum selection clause to the contrary, jurisdiction should be permitted if consistent with minimum due process requirements. Even in passive purchaser situations, failure to restructure the transaction should not automatically suggest an inability to do so, where the transaction is of considerable magnitude or for unique goods. ${ }^{135}$

\section{Summary}

The rules proposed here strike the proper balance between state jurisdictional interests and the federal interest in encouraging interstate commerce. The federal interest is satisfied, because it requires only the protection of those who are unaware that a transaction might lead to suit in the forum and of those who would be unable to conduct interstate transactions if they had to bear the risk of jurisdictional liability. The interests of the state are protected, because it may assert jurisdiction over anyone who has significant commercial contacts with it. The interests of commercial actors also are protected, because they can predict witl some certainty where their conduct will render them hable to suit. ${ }^{116}$ The

214 In World-Wide Volkswagen Corp. v. Woodson, 444 U.S. 286, 297 (1980), the Supreme Court stated that when a commercial defendant "has clear notice that it is subject to suit [in the forum state it] can act to alleviate the risk of burdensome litigation by procuring insurance, passing the expected costs on to customers, or, if the risks are too great, severing its connection with the state." The rules developed here reject the final alternative, for the coinmerce clause requires that commercial actors not be forced to choose between forgoing an interstate transaction or accepting the risk of being subject to suit in a distant state. Soine protective action short of giving up the transaction must be available.

${ }^{125}$ But see Whittaker Corp. v. United Aircraft Corp., 482 F.2d 1079 (1st Cir. 1973), where three out-of-state defendants each entered into contracts of similar magnitude to purchase the same goods from the plaintiff. One defendant actively participated in the production process by providing specifications and sending representatives to oversee the process. The other two defendants merely asked for what the first one received. Jurisdiction was upheld as to the first defendant and denied as to the other two. The rules outlined above would reject the formalistic active/passive distinction and focus instead on the magnitude and underlying character of the transaction.

116 The rules focus on the reasonable expectations of parties to a transaction. Contrast Lakeside Bridge \& Steel Co. v. Mountain State Constr. Co., 597 F.2d 596 (7th Cir. 1979), 
rules therefore encourage efficient treatment of potential jurisdictional costs in interstate transactions: when a person is aware of a potential cost-that is, when he realizes that he and the other party to a transaction have different jurisdictional preferences-he must consider that potential cost in structuring the transaction.

\section{CONCLUSION}

This comment has argued that the current balancing approach used in long arm analysis should be replaced with a body of fixed rules. The proposed rules generally are consistent with the results of decided cases, but provide a coherent framework for analysis that emphasizes predictabihty of result and fidelity to the Constitution.

Under this analysis, due process in the exercise of the long arm is provided by minimum requirements of causation, notice, and relevance. These standards give individuals a sufficient opportunity to avoid a forum's jurisdiction and ensure that the forum has a legitimate interest in regulating the conduct at issue. These due process requirements will allow states expansive long arm power. If further limits on the long arm are imposed, they must be grounded on a constitutional principle restricting a state's power to regulate the particular conduct at issue. Using commercial cases as an illustration, this comment has explored the jurisdictional ramifications of the negative commerce clause. The implications of other constitutional guarantees remain for future study.

Mark P. Gergen

cert. denied, 445 U.S. 907 (1980), denying jurisdiction over a defendant who entered into a contract that elicited another's performance in the state because performance there was not required by the contract. The court distinguished between defendants who know a contract will elicit performance in the forum and those who insist on performance there. Yet both are equally able to take protective measures in light of the risk of being sued in the forum. The court argued that absent such a rule, a party to a contract could potentially be liable to suit wherever the otlier party chose to perform. $597 \mathrm{~F} .2 \mathrm{~d}$ at 603 . A party will be liable to suit in the forum state, however, only when he reasonably might have expected the otlier party to perform there. Moreover, the rules offered here would ensure that he lad an opportunity to take protective measures in liglit of tliat risk. The Seventh Circuit elevated form over substance by focusing on the formal provisions of the contract ratlier than on the reasonable expectations of the parties to the contract. Cf. Note, Lakeside Bridge \& Steel Co. v. Mountain State Construction Co.: Inflexible Application of Long-Arm Jurisdiction Standards to the Nonresident Purchaser, 75 Nw. U.L. REv. 345, 347 (1980) (criticizing Lakeside Bridge rule for its rigidity). 